
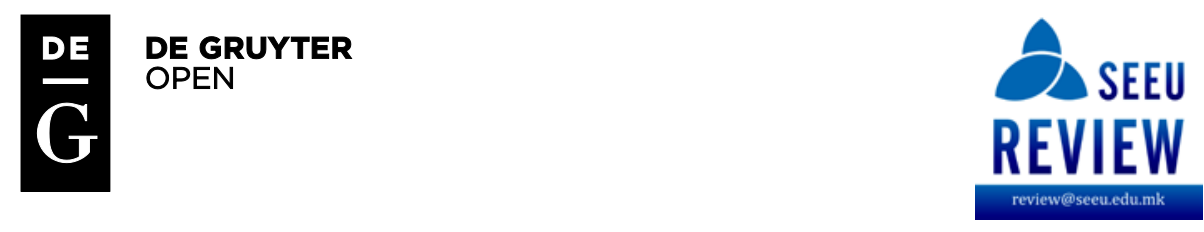

\title{
POPULATION AGING IN ALBANIAN POST-SOCIALIST SOCIETY: IMPLICATIONS FOR CARE AND FAMILY LIFE
}

\section{Merita Meçe}

International Family and Community Studies, Clemson University, USA e-mail:mmece@g.clemson.edu

\section{DOI: 10.1515/seeur-2015-0033}

\begin{abstract}
Population aging is becoming an inevitable phenomenon in Albanian postsocialist society, posing multi-faceted challenges to its individuals, families and society as a whole. Since 1991, the Albanian population has been exposed to intensive demographic changes caused by unintended aspects of socioeconomic transition from a planned socialist economy to a market-oriented capitalist one (Hoff, 2008). Ongoing processes of re-organization of social institutions increased its socio-economic insecurity leading to the application of various coping mechanisms. While adjusting themselves to other aspects of life, people changed their decisions of having children and leaving the country (Hoff, 2008). On the other hand, replacement of former traditional extended family forms with diverse living arrangements and family structures has been the outcome of the combination of three factors: falling fertility, increasing life expectancy and increasing migration (INSTAT, 2014).

However, family remains the basic social unit that provides support, care and protection for its old members even though its capacities are diminishing. Family Life Cycle Theory views family development as a series of stages where family members deal with various developmental tasks and play different roles as they move from one stage to another.
\end{abstract}


This paper examines population aging in Albanian post-socialist society (after 1990). Based on Family Life Cycle Theory and Family Development Theory, it reviews literature and uses secondary data to discuss its implications for elderly care and family life. It concludes that population aging requires better understanding of this process in order to facilitate a series of family adaptations to respond to the changing needs of its elderly members.

Key words: old age, population aging, care for old family members, old age dependency ratio.

\section{Introduction}

Aging of the human population in Europe became a reality at the beginning of the twenty first century (Palloni, 2009). Data indicate that during the period 1950-2010 old age population (65 years and above) increased from 8.7 percent to 16.1 percent, while population aged 0-14 years declined from 25.4 percent to 17.6 percent (Warnes, 1998). In this context, Albania has not been isolated from psychological, social, medical, cultural and economic aspects of this phenomenon. Evidence indicates that they have disproportionally impacted the balance of its population among different age-groups (Aleksandrova \& Velkova, 2003; Długosz, 2011) threatening or weakening existing mechanisms of elderly support (Palloni, 2009).

Research indicates that the intensity of population aging in Albania reflects the unintended side effect of the socio-economic transition from a centralized economy to a market-oriented one (Hoff, 2008). Its dynamics have changed unwritten social contracts of intergenerational relations reducing their social contact and restricting the supply of care for older generations (Palloni, 2009). On the other hand, family life is an interactive process that progresses through its stages (Goldenberger \& Goldenberger, 2004). Life after retirement is part of the life cycle that involves different stages and types of experience (Barker \& Bury, 1978). Families are changing and new family living arrangements are becoming diverse, challenging their traditional role and responsibility (Rice, 1994).

This paper seeks to examine the dynamics of population aging in Albanian post-socialist society and to discuss their implications for family life and care based on Family Life Cycle Theory and Family Development Theory. Following the introduction, the paper addresses the definition of old age, the aging process and its characteristics in Albania. It provides a general overview of the population aging trends analyzing their causes and key characteristics. The next section of the paper draws on the concepts of the Family Life Cycle 
Theory and Family Development Theory to explain the change of the family developmental tasks as it moves from one stage to another. The final section focuses on the implications of population aging in family life with special emphasis on the changing family living arrangements, family care and protection for its old members, intergenerational transfers, vulnerability and adjustment to later life.

\section{Definition of Old Age, the Population Aging Aspects and its Characteristics}

There is no universally agreed definition of old age in purely chronological terms, because this concept does not have the same meaning in all societies and changes with the increase of life expectancy (Lloyd-Sherlock, 2000; Sanderson \& Scherbov, 2008; Tinker, 2002; UN, 2007). Each country has its own history of culture, socio-economic development and public health improvement which has to be taken into account when considering the definition of old age (Sanderson \& Scherbov, 2008). For instance, people are considered old when they are in retirement age (Tinker, 2002; UN, 2007) which in some countries corresponds with 60 years old and over, while in some others corresponds with 65 years old and over (UN, 2007). Often people are considered to be old not because they are thought to be close to the end of their expected life span, but because they have undergone in certain changes in their social roles and activities (UN, 2007). Retirement can be seen as a period of life where increasing number of people look forward (Barker \& Bury, 1978).

A fluid concept of old age is culturally bound (Carstensen \& Fried, 2012; Rueda \& Ferreira, 2012; UN, 2007). Humans are creatures of culture and their life course is culturally constructed. They look to culture to tell them when to marry, start families, work and retire (Carstensen \& Fried, 2012). Regardless of the cultural variations of its meaning, old age is generally viewed to cover a wide span of three decades. Therefore the majority of cultures distinguish between the "young old" group (defined as 65 - 74 years), "old old" group (defined as 75 - 84 years) and "oldest old" group (defined as 85 years and above) (Gondo, 2012; Lloyd-Sherlock, 2000).

Population aging is perceived as an inevitable process (Muenz, 2007; UN, 2007) and it is viewed from different aspects, respectively, biological, social and demographic ones. As a biological reality, population aging is defined as the outcome of progressive accumulation of body changes over time that lead to an increase of the probability of disease and death of the individual 
(Harman, 1956). The dynamics of this process go beyond human control. Physiological deterioration gradually impairs an individual's ability to function and he loses his capacity to maintain his internal milieu (Gorman, 1999; UN, 2007; Vină, Borràs \& Miquel, 2007).

Strehler (1977) identified four characteristics of population aging: (a) population aging as universal process (that must occur in all individuals in different degrees); (b) population aging as an intrinsic process (that must be caused by endogenous factors rather than extrinsic ones); (c) population aging as progressive process (that must occur progressively throughout individual's life span); and (d) population aging as deleterious process (meaning that a phenomenon of population aging will be considered as part of it if it is seen as "being bad" for the individual). In fact, a large body of literature has been focused on deficiencies of old age including memory impairment, difficult concentration and slow cognitive processing (Crastensen \& Fried, 2012).

As a social construct, population aging is closely linked with the society where the concept of old age makes sense. In some societies, for instance, loss of some roles due to physical decline is seen as a key element to define old age. From this perspective, old age is seen to begin at the point where active contribution of the people is no longer possible (Gorman, 1999).

In addition, demographic aging is defined as an increase of the proportion of the population aged 65 years and over compared to the total population (Lloyd-Sherlock, 2000; Tinker, 2000). The changing balance between proportions of different age-groups has changed the age structure of the total population generating a critical mismatch between cultural norms that guide us through life and the length of our life (Riley, Kahn, Foner \& Karin, 1994). In this paper, age 65 is taken as a cut-off point between the old and young cohorts of the population of Albania.

\section{General Overview of Population Aging in Albanian post-socialist society}

Population aging in Albania is becoming a transforming demographic force that is reshaping the demographic landscape of the country (Jakovljević \& Laaser, 2015; NIA \& NIH, 2012). The timing of this process has been influenced by complex interdependent factors but the most important ones include the pace of demographic transition and the specific socio-economic and political situation of the country (Vojković, Magdaenić \& Živanović, 2014). More specifically, demographic aging is the result of the combined effects of increased life expectancy leading to a growing share of an older 
population, decreasing birth rates causing decrease of younger age population and the significant migration of young people contributing to a decrease of their share in the total population (Hoff, 2008).

In historical terms, in the 1950s, Albania had the youngest population among Western Balkan countries with a total fertility rate of six children per woman followed by Bosnia and Herzegovina with almost five children for every woman, while Macedonia and Montenegro had four children for every woman. Almost sixty years later we have a different scenario of the profile of the population. Low fertility rate combined with high life expectancy at birth have impacted natural population change (birth rate minus death rate) (Jakovljević \& Laasar, 2015) (Table 1).

Table 1: Key Demographic Indicators of Population Aging in Albania and Western Balkan Countries, 1950-2011

\begin{tabular}{|c|c|c|c|c|c|c|c|c|c|c|c|c|c|}
\hline \multirow[t]{2}{*}{ Countries } & \multicolumn{4}{|c|}{$\begin{array}{l}\text { Total population (in } \\
\text { millions) }\end{array}$} & \multicolumn{3}{|c|}{ Total fertility rate } & \multicolumn{2}{|c|}{$\begin{array}{l}\text { Natural } \\
\text { population } \\
\text { change (in } \\
\text { percentage) }\end{array}$} & \multicolumn{4}{|c|}{ Life expectancy at birth } \\
\hline & 1950 & 1991 & 2010 & 2011 & $\begin{array}{c}1950 \\
- \\
1955\end{array}$ & $\begin{array}{c}2005 \\
- \\
2010\end{array}$ & 2011 & $\begin{array}{c}1950 \\
- \\
1955\end{array}$ & $\begin{array}{c}2005 \\
- \\
2010\end{array}$ & $\begin{array}{c}1950 \\
- \\
1955\end{array}$ & 1991 & $\begin{array}{c}2005 \\
- \\
2010\end{array}$ & 2011 \\
\hline Albania & 1.2 & 3.26 & 3.2 & 2.83 & 6.1 & 1.8 & 1.52 & 2.7 & -0.29 & 55.3 & 71.5 & 76.3 & 77.0 \\
\hline $\begin{array}{l}\text { Bosnia and } \\
\text { Herzegovina }\end{array}$ & 2.7 & 4.52 & 3.8 & 3.84 & 4.8 & 1.2 & 1.15 & 2.5 & -0.2 & 53.7 & 66.4 & 75.5 & 75.6 \\
\hline FYROM & 1.3 & 1.89 & 2.1 & 2.06 & 4.0 & 1.5 & 1.46 & 1.8 & 0.1 & 54.9 & 71.5 & 74.4 & 74.7 \\
\hline Montenegro & 0.4 & 0.62 & 0.6 & 0.62 & 4.0 & 1.7 & 1.77 & 2.2 & 0.1 & 59.8 & 75.6 & 74.2 & 75.0 \\
\hline Serbia & 6.7 & 7.82 & 9.6 & 7.27 & 3.2 & 1.4 & 1.4 & 1.5 & -0.6 & 59.1 & 71.0 & 73.3 & 74.1 \\
\hline
\end{tabular}

Source: Jakovljević \& Laaser. (2015); Vojković, Magdaenić \& Živanović. (2014).

During the period 1950-1990, Albania had a pro-natalist policy where a virtual absence of abortion and contraception was evident. Therefore, when the political system collapsed in the 1990s, it came as a surprise to see that the total fertility rate had fallen to around three children per woman (Gjonça, Aassve \& Mencarini, 2008). One of the factors of fertility decline has been education of the population, in general, and education of women, in particular (Falkingham \& Gjonça, 2001). But lack of individual data makes it difficult to build any fertility history during this period and quantify the role of educational effect (Gjonça, Aassve \& Mencarini, 2008). 
In Albania, during the years of the socialist system (1945-1990), internal movement of the population was strictly regulated by the government, while international migration was almost inexistent because it was illegal and punishable (Gedeshi \& Jorgoni, 2012). The collapse of the socialist system by the beginning of the 1990s found Albanians unprepared for dramatic changes in their lives. They had to adjust both their beliefs and expectations to cope with hardship previously unknown to them (poverty, unemployment, social exclusion) (Hoff, 2008). Therefore, immediate opening of the country's borders along with chaotic transformation of the economy led to massive migration of almost 700,000 Albanians in search of a better life abroad (Gedeshi \& Jorgoni, 2012; INSTAT, 2012). International migration that initially started spontaneously became later on very intensive and by the end of 2011 about 1.4 million persons were estimated to be living abroad (WB, 2011).

Fertility decline and increasing life expectancy at birth have reversed the population age pyramid, shrinking the total number of the young age-group $(0-14)$ and working age-group (15-64) while increasing the number and share of older people (Muenz, 2007). Demographic processes show a shift of the Albanian society from being quantitatively dominated by younger cohorts to a society where elderly people represent a considerable share of the total population (Kirk, 1996; Muenz, 2007) (Figure 1).

Figure 1: Population distribution in Albania (in percentage) based on data taken from censuses, 1989-2011)

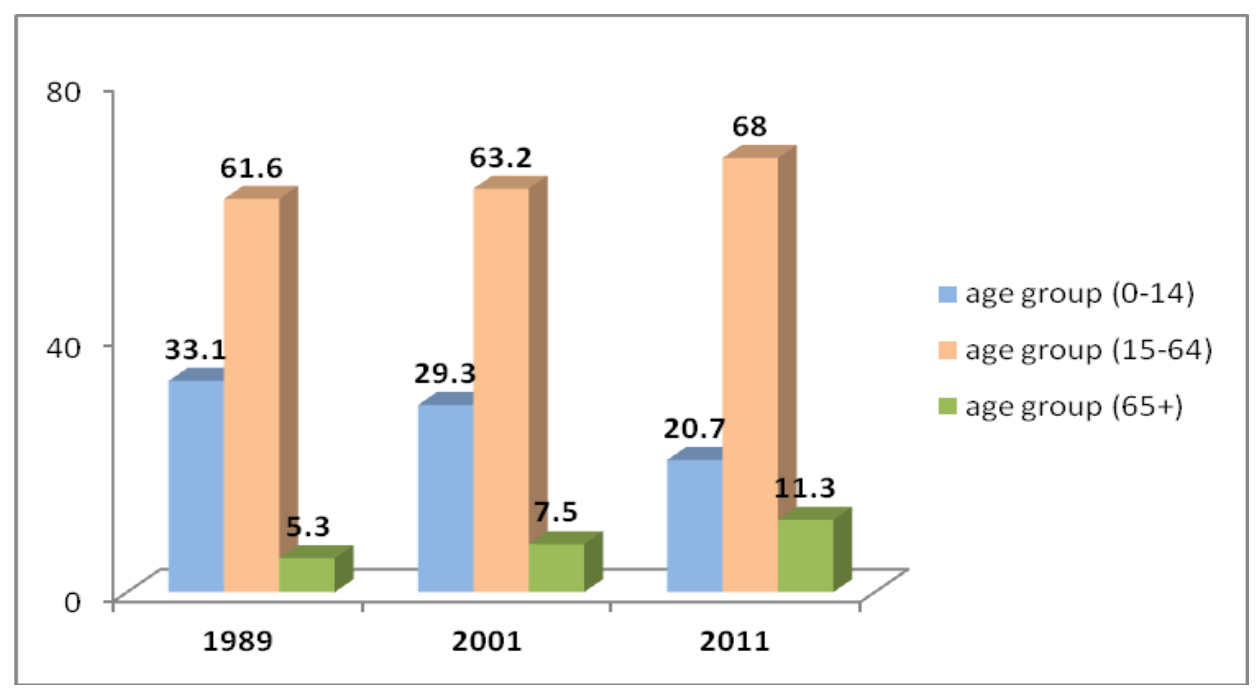

Source: INSTAT. (2014). 
The change of the age structure of the total population led to the growing imbalances between the working age population and elderly people, calling into question support mechanisms during the later life (Jakovljević \& Laasar, 2015). The change of these balances led to the change of the old dependency ratio (defined as the total number of people 65 years old and above per 100 people aged 15-64 years old) and the potential support ratio (defined as the total number of persons 15-64 years old per population 65 years old and above). Figure 2 shows that during the period between three censuses (19892011) they changed in the opposite direction.

Figure 2: Old Dependency Ratio and Potential Support ratio in Albania, 1989-2011

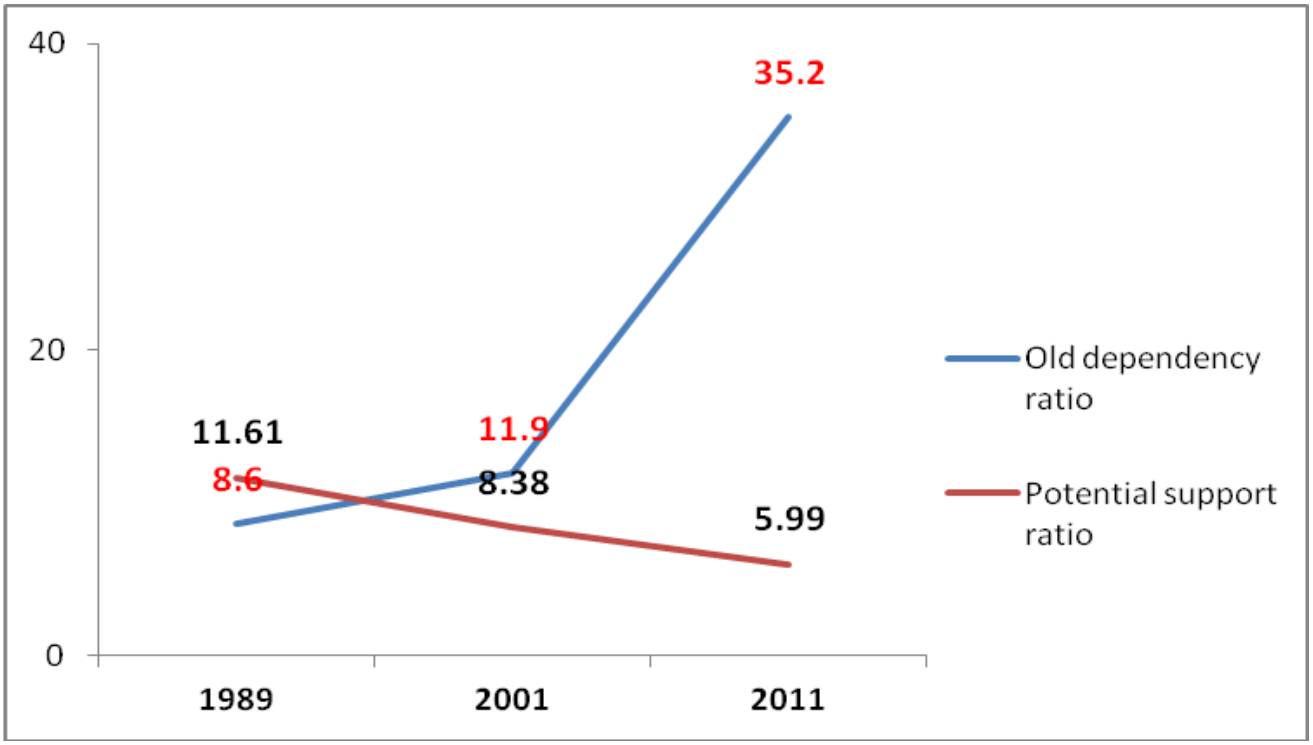

Source: INSTAT. (2014).

\section{Gender Differences in the Demographics of Aging}

Population aging in Albania is characterized by a significant gender gap. The proportion of old women tends to substantially increase as age advances (NIA \& NIH, 2012) (Table 2).

Table 2: Life Expectance at Birth, by Sex in Albania and Western Balkan Countries, 1990-2012 


\begin{tabular}{|c|c|c|c|c|c|c|c|c|c|}
\hline $\begin{array}{c}\text { Life expectancy } \\
\text { at birth }\end{array}$ & \multicolumn{4}{|c|}{1990} & \multicolumn{3}{c|}{2000} & \multicolumn{3}{c|}{2012} \\
\hline & Male & Female & Both & Male & Female & Both & Male & Female & Both \\
\hline Albania & 67 & 71 & 69 & 68 & 73 & 70 & 74 & 75 & 74 \\
\hline $\begin{array}{c}\text { Bosnia and } \\
\text { Herzegovina }\end{array}$ & 70 & 75 & 73 & 72 & 78 & 75 & 75 & 80 & 77 \\
\hline FYROM & 70 & 75 & 72 & 71 & 76 & 73 & 73 & 78 & 76 \\
\hline Montenegro & 73 & 79 & 76 & 72 & 77 & 75 & 73 & 78 & 76 \\
\hline Serbia & 69 & 75 & 72 & 72 & 80 & 76 & 77 & 83 & 80 \\
\hline
\end{tabular}

Source: WHO. (2014). World Health Statistics.

This demographic gender imbalance has led to different gender outcomes:

- increased disability rate with age. Therefore, more older women live with disabilities than older men in later life (Zahidi, 2012);

- increased old-age health problems, which are rooted in early life expectancies and living conditions. Therefore, poor women with low socio-economic status who enter into old age might have more serious problems than old men do.

- different gender expectations for caring for themselves and others, based on prevailing social norms. Older women not older men are usually called upon to be caregivers themselves and care for others even though they are disabled (Zahidi, 2012).

There are no clear data about old age among minority groups in Albania during the period 1990-2011. Either they have not been registered as ethnic affiliations or because specific questions about ethnic group membership have not been included in data collection through the official census over the years. However, data from the 2011 Census indicate that 83 per cent of the population self-declared as Albanians, while 2 per cent of the population selfdeclared as belonging to ethnic minority groups (Greeks, Macedonians and Montenegrins) and ethno-linguistic groups (Roma and Vlachs). The Roma population is young and Figure 3 shows distribution of Roma and Albanian population by age-groups (INSTAT, 2015). 
Figure 3: Distribution of Roma and Albanian population by age groups, 2011

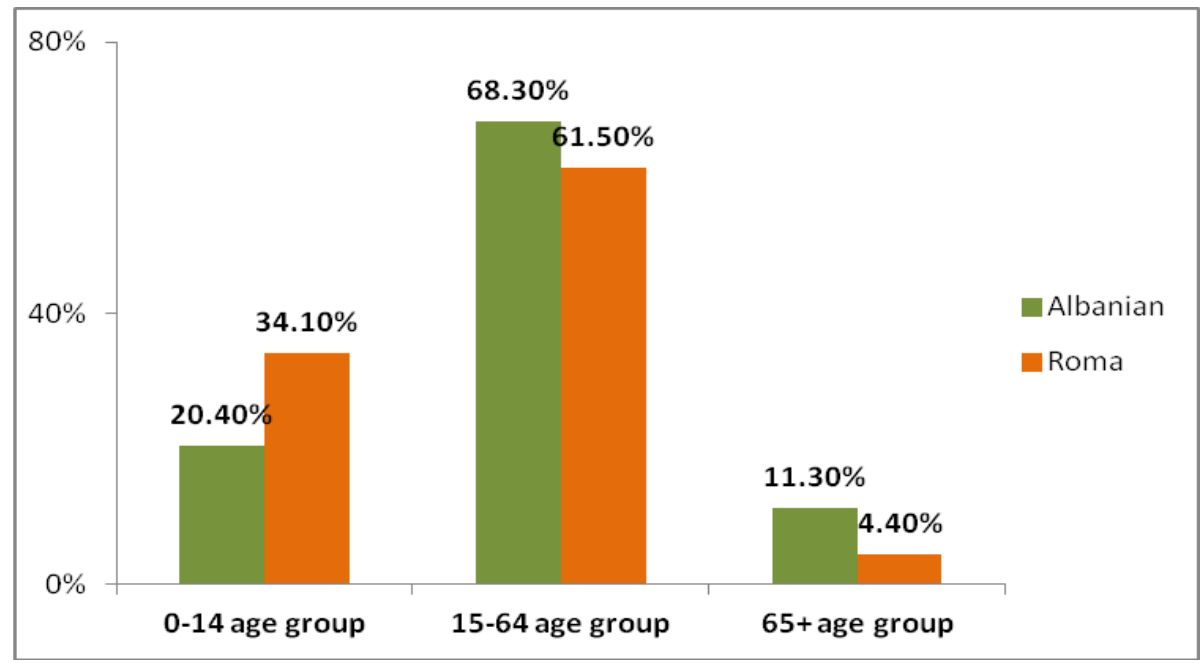

Source: INSTAT. (2015)

\section{Aging in Family Life Cycle Theory and Family Development Theory}

Family Life Cycle Theory, conceptualized by Duvall and Hill (1948), has integrated two formulations: (a) the concept of symbolic interactionism orientation that views the family as an arena of interacting personalities (Burgess, 1931), and (b) the concept of the phasing of human development where complex developmental tasks are mastered over the entire life span (Havinghurst, 1953). Therefore, the family acts as an organization where its growing and changing members are reciprocally engaged in several changing developmental tasks and enable each other to work together through them over the life span (Hill, 1986).

Family Development Theory views family as an interdependent system over its natural history of formation, expansion, contraction and dissolution. It focuses on the changing role content of positions that usually follow changes in norms for these positions (Hill, 1986). Family developmental stages change whenever there is a marked break in the family positions and the role content within them. For instance, new stages of development occur through marriage, births and death. They are followed by a marked change of age role content of one or several positions within the family requiring a rearrangement of role reciprocities (Hill, 1986). Therefore, Family Development Theory enables 
family members to anticipate stress which normally appears within the family at the beginning of the cycle, growing up and breaking up toward the end of the life span (Hill 1986).

Family life stages, namely related to the change of family size, the developmental age of the oldest child and the change of the breadwinners' work status, are viewed as periods characterized by relative equilibrium with high consensus about role allocation (Hill, 1986). Consensus maintenance about division of tasks within the changing family, equitable allocation of family resources, competence levels of family members in task performance, and completion and fulfilment of their emergent needs are important to assure their matching (Hill, 1986).

Family Life Cycle Theory involves an eight-stage theory based on epigenetic principles of successive change in development (Erickson, 2007). It outlines respective developmental tasks telescoped in mutually exclusive stages of family development (Hill, 1986):

Stage 1 - Establishment stage (new marrieds trying to establish a mutually satisfying marriage, adjusting to pregnancy and kin network).

Stage 2 - First parenthood (having an infant, adjusting to new parental role, creating a pleasant home environment for the child(ren) and the parents).

Stage 3 - Family with pre-school aged child(ren) (adjusting to the needs of pre-school children, coping with lack of privacy as parents).

Stage 4 - Family with school aged child(ren) (encouraging educational achievements of children and fitting into the community).

Stage 5 - Family with adolescents (trying to balance freedom with responsibility and establish post-parental interests).

Stage 6- Family as launching centre (trying to maintain a supportive home base and launching youth into adulthood).

Stage 7 - Family in middle years (post-parental empty nests trying to maintain ties among old and young generations, and refocusing on marriage relationships).

Stage 8 - Family in retirement (adjusting to retirement, coping with loneliness and death) (Hill, 1986). 
In 1980s, the concept of family life cycle was broadened by Carter and McGoldrick (1999). They included a multidimensional, multicultural, multigenerational perspective expanding it within an individual, family and socio-cultural framework (Carter \& McGoldrick, 1999). They argued that the family life cycle approach presents a natural context that frames individual identity and development to respond to the effects of the social system. Therefore, individual life cycles that take place within the family life cycle interplay and affect the relationship system within the family. As family moves from one stage to another, it should be flexible to sustain both the entry and exit of its members (Goldenberg \& Goldenberg, 2004).

Carter and McGoldrick (1999) argued that generations within the family have a reciprocal life-shaping impact on one another. From a multigenerational perspective, family life is characterized by continuity and change as the family system moves through time. Therefore, various intergenerational transactions take place within the family in a certain development phase (Carter \& McGoldrick, 1999). As one generation copes with issues related to aging, the other one tries to deal with the decision of children to leave home or plan starting an intimate adult relationship. Since the family life cycle progresses in stages, roles assigned to its members, closeness between them and boundaries among them are continuously defined and redefined. Therefore, a family experiences periods of transition, relative stability and change while its members try to cope with changing life circumstances' demands (Goldenberg \& Goldenberg, 2004).

Despite differences in size, structure, composition or cultural context, the majority of the families progress through certain predictable phases (Goldenberg \& Goldenberg, 2004). They require negotiations to avoid being blocked at a particular development phase or fail to make necessary transition in due time (Barnhill \& Longo, 1978). However, Kliman and Madsen (1999) argued that negotiations of family life cycle transition are culturally bounded and embedded in social class. According to them, social class determined opportunities, options and privileges of family members to use resources and cope with transitions. Since social class lifestyle and cultural background are interrelated, they play a crucial role in how the family proceeds through its life cycle and tasks considered relevant at each phase (Goldenberg \& Goldenberg, 2004).

Family relationships undergo transitions during family life cycle stages. These transitions require transformations in the organization of the family system. Changes do not have the same pace and pattern. Some of them are gradual and continuous, while the others are disruptive and discontinuous. However, considering the diversity of the families in this new century, these 
stages do not fit every family (Goldenberg \& Goldenberg, 2004). Zilbach (1989) argued that while moving from one stage to another, the family development proceeds from one task accomplishment to another. If a particular set of tasks remains incomplete in a certain stage, then family development is delayed. Therefore, these difficulties are carried into subsequent stage. Families continue to change and evolve. Changes brought about by retirement present major adaptation challenges for the family system (Walsh, 1999).

\section{Implications of Population Aging for Family Life}

Population aging presents numerous challenges and raises various issues because different age groups have different needs (Vojković, Magdaenić \& Živanović, 2014). Standing (1996) has pointed out that countries of the previous socialist camp lost three main pillars of economic security during their process of transformation to a market economy, respectively, a) guaranteed employment from completion of their full-time education to retirement; b) social protection through government subsidies; c) various enterprise in-kind social benefits.

This next section discusses implications of population aging on: (a) family obligations and intergenerational emotional complexity; (b) diverse family structures and living arrangements; (c) family role and function; (d) care giving and support; and (e) consumption needs and living standards.

\section{Family Obligations and Intergenerational Emotional Complexity}

The change of the family structure because of population aging does not imply that the supporting role of the family to its old members has decreased its importance (Harper \& Levin, 2003). In modern societies, there are various competing demands and multifaceted roles of the family members which reveal the complexity of the process of family care giving in changing cultural settings. Therefore, as the family structure changes over time along with the change of intra-family relationships, recognition of the changing of the cultural context of care giving is important (Harper \& Levin, 2003).

Stein (1992) studied family obligations within the context of norms, obligations and reciprocities. He distinguished three types of obligations: (a) felt obligation, (b) relational obligation, and c) filial responsibility. Stein et al. 
(1998) defined felt obligation as expected appropriate behaviour perceived within the context of personal relationship within kin across the life course. He identified five main dimensions of felt obligation related to expectations about personal sharing, self-sufficiency, assistance, conflict avoidance, and participation in family rituals. His study found that young children expressed higher felt obligation than adults, while adults with two living parents expressed lower felt obligation than adults with one living parent. Stein et al. (1998) define relational obligation as an alternative approach to alleviate a child's sense of guilty. In this case, assistance is provided in return for efforts made during a child rearing period. Filial responsibility is defined as an obligation that derives from the social norms of the society which oblige adult children to take care of their old parents. Therefore, the complexity of interactions faced by family members who care for old generations places multi-faceted strains on them, in general, and on their careers in particular (Herlitz \& Dahlberg, 1999).

On the other hand, high mobility of young people due to rural-urban income disparities and migration of adult children to cities or abroad for a better life has increased emotional detachment among generations. Many old parents feel disconnected from their adult children and gradually become symbolic strangers to them. Often elderly parents lack literacy skills or have poor utilization of advanced communication tools. These have hindered their regular contact and deepened the communication gap (Giddens, 1991; UN, 2007).

In a traditional Albanian family, parents live with one of their children (usually the youngest one) who cares for them. But increased internal and international migration during the years of transition has created a new social phenomenon of the abandoned elders known as 'orphan pensioners' (De Soto et al., 2002).

\section{Diverse Family Structures and Living Arrangements}

There is a rapid change of the social environment where people grow old. This magnitude is very unpredictable because family size is decreasing and the role of extended family is diminishing while caring for old generations is changing (UN, 2007). However, population aging has increased the possibility of the changing nature of inter-generational relationships within the family (Bornat et al, 1999). 
Giddens (1991) identified two scenarios to address these implications. The optimistic one represents a shift from restrictive normative roles towards more equitable family relationships. Taking into consideration that modernity increases fragmentation and decreases unification, individuals within the family should be more open to new forms of relationships and transfer of resources within the family. The pessimistic one views moral decline and social fragmentation of elderly people who would become worse in their individualistic battle for survival. They will be without contact with family careers or grandchildren. The transfer of resources between family members might change following family reconstitution (Bornat et al., 1999). The main changes in family structures of the last decades show increased divorce rates, remarriage, stepfamily formation, cohabitation and childlessness (Silverstein \& Garrusso, 2010; UN, 2007).

Research has indicated that parental divorce and stepfamily formation have had detrimental effects on interconnecting and supportive relationships of adult children for their elderly parents (Bornat et al., 1999; Lin, 2008; Pezzin, Pollak \& Schone, 2008). Unequal distribution of intergenerational relationships has been viewed among mothers and fathers after divorce. This has brought into question the support resources of fragile elderly parents who come from historically high divorce rates and remarriages (Pezzin, Pollak \& Schone, 2008; Silverstein \& Garrusso, 2010). Filial commitment has been weaker toward older stepparents than toward older biological parents (Coleman, Canong \& Rothrauff, 2006). Adult stepchildren have been a fragile safety net for aging stepparents (Silverstein \& Garrusso, 2010). Since divorce and remarriage are becoming increasingly common, the change of the relationship between partnership disruption and support to elderly people is becoming inevitable (Glaser, Tomassini \& Agree, 2009).

Cohabitation of middle-aged and older adults represents a new living arrangement of aging families. However, old cohabiters seem to be at greater risk of being institutionalized compared to their married counterparts because cohabiting unions are less likely to count on a committed partner responsible for care giving in home. Research has indicated deleterious consequences in later life caused by instability of such non-marital unions (Silverstein \& Garrusso, 2010).

Childless old couples represent a significant change in family structure due to lack of transaction of intergenerational lineages. During their life course they have been adapted to their financial resources and have developed other social alternatives instead of having children (Silverstein \& Garrusso, 2010). The shift from extended a traditional family to a nuclear family and the 
increase of one-person households has exposed old people to various living arrangements and vulnerability.

The growing tendency of generations to live separately in small units has challenged the rising number of old people who live alone (NIA \& NIH, 2012; UN, 2007). On the other hand, reduced fertility and high migration rates of young generations (from rural to urban areas, and abroad to developed Western countries) have left no other options to elderly parents except that of living alone. Many of them have lost their daily contacts and relationships with their adult children. In the past, living alone in old age was not supported by social norms. It was often equated with family abandonment or social neglect (NIA \& NIH, 2012). But during the last several decades, these traditional norms do not seem to be as prevalent (Gierveld, 2009).

Living independently might be seen positive as long as the elderly people are able to maintain their quality of life, enjoy their rights and keep the status quo of their life style. The risk of independence loss becomes high among childless old couples who lose social contacts and kin relationships (Gierveld, 2009). Therefore, decreasing of the size of the social network might expose elderly people to loneliness (Kohli, 2004).

There are limited data and studies about cohabitation in Albania (INSTAT, 2014). Results of Albanian Demographic and Health Survey 2008-2009 showed that it has been mainly practiced among young age groups respectively, at 3 per cent of females aged 20-24 years and 4 per cent of males aged 25-29 years (INSTAT et al., 2010). Besides this, marriage and divorce have moved in two different directions. While the total number of marriages has been significantly decreased, the total number of divorces has been increased (Table 3).

Table 3: Marriage and divorce in Albania, 1990-2011

\begin{tabular}{|c|c|c|c|}
\hline & 1990 & 2001 & 2011 \\
\hline General Marriage Coefficient & 13.3 & 11.8 & 11.5 \\
\hline Number of divorces & 2675 & 2462 & 3642 \\
\hline Divorces per 100 marriages & 9.2 & 9.6 & 14.3 \\
\hline
\end{tabular}

Source: INSTAT. (2014)

The number of multigenerational families varies in Albania. However, generally there has been gradual increase in the tendency towards solitary living (Ševo et al., 2009). Solitary living has different gender outcomes 
because women tend to live longer than men. Increasing numbers of old women living alone may increase elderly women's isolation and challenges with care giving arrangements. This is very problematic because social programmes and institutions to support families are inadequate all over the country. Therefore the responsibility for care giving mainly falls on the shoulders of kin and family members (UN, 2007).

\section{Family Role and Function}

Relationships in aging families are interdependent and largely embedded in cultural context. In traditional societies, families survived through mutual exchange across generations (Sun, 2002). After 1991 in Western European countries, for instance, more financial transfers have been directed from parents to adult children than in the other direction because of pension schemes and other support institutions responsible for the well-being of elderly citizens in these nations (Albertini, Kohli \& Vogel, 2007).

In the case of Albania, as in other developing countries, old parents tend to contribute to the multigenerational family by contributing their modest monthly allowance from pensions to the family income, providing family labour, being involved in family chores and caring for grandchildren (Frankenberg, Lillard \& Willis, 2002; Ševo et al., 2009). When old parents do not receive a monthly payment from pensions, their adult children are expected to support them with scarce resources. However, the high unemployment rate among the young generation combined with economic instability and a fragile social support system for the family have posed risks to the well-being of elderly parents and their quality of life (Ševo et al., 2009).

Research has shown that there are differences in family attitudes towards aging parents. Intergenerational in-home exchange of support and care of older generations is not always supported by younger family members. There is an imbalance in support giving and receiving because the old generation takes the larger part of the family burden in exchange for co-residence (Kohli, 2004). Traditional social norms value elderly people and respect them. The diverse family structures may increase the risk of deprivation, victimization and marginalization of intra-family resource allocation for elderly members. Since elderly people will not enjoy the same levels of respect and inclusion as the worker cohort can enjoy, they will benefit less from resource allocation within the family (Ferreira, 2009). This is more evident when they lack resources for young family members (NIA \& NIH, 2012). 
Deprivation, victimization and marginalization have diverse gender implications. Often old women have low or no income because of their dependency on their husband's economic resources during their lifetime or because they have been employed in low-paid jobs. Women live longer than men and widowed women rarely remarry compared to widowed men who usually remarry young women. Therefore, poor widowed old women outnumber widowed old men. Lack of economic resources has increased the risk of dependency of old widowed women to neglect, social isolation and deprivation (Zahidi, 2012).

\section{Care giving and Support}

Rising life expectancy has increased the total number of people at very old ages. However, research has indicated that the majority of health issues in old age have stemmed from health conditions early in life (NIA \& NIH, 2012). A growing body of evidence has proved that population aging has increased the prevalence of diseases among elderly people (Christen et al., 2009). Increases in pain and psychological distress along with the increase of multiple symptoms are highly correlated with the rise of chronic disease prevalence (Christen et al., 2009). Sex variations in morbidity and disease are common due to biological differences between men and women. Old women tend to have more non-life threatening diseases than old men (Christen et al., 2009).

As people age, their body functioning deteriorates over time. In old age, old people are able to function and conserve their identity. When they become very old (older than 85 years) they are more vulnerable, have little identity, psychological autonomy and personal control (Baltes and Smith, 2003). But mobility is not a pure mechanical function. It helps people achieve personal goals and be active. Those who are usually housebound suffer from limited social and material resources (Barker \& Bury, 1978). Tunstall (1966) distinguished between individuals who are temporarily housebound and those who are permanently housebound. Temporarily housebound individuals are those who are confined at home for at least six months. Lack of mobility has a detrimental impact in terms of individual's life norms and family's life norms. Lack of mobility is not only related to a stereotype attached to a person who is old, ill or does not contribute at home in return to care giving. It also increases anxiety and family conflict because the elderly person is always waiting for someone to take them out and give them company (Barker \& Bury, 1978). Tunstall (1966) found that inactivity of household elderly people reduced their self-confidence and increased their feeling of depression. Lack 
of family support increases their life risk and vulnerability if no external resources will be of help.

In Albania, informal care within the family is fading during the years of transition. 'Care drain' is becoming evident and the new 'culture of distance' is embracing the family. Research indicates that Albanian families with a close relative abroad, as an average, have an increased number of members aged 65 and above and a reduced number of minors (Bordogna, 2013). But Albanian state services are unprepared and unable to provide necessary care services to elderly people in need. In general, there is a scarcity of specialized institutions for this category (Gedeshi \& Gjokuta, 2008). In total, there are only six public elderly homes with a capacity of 400 places and 10 private homes with a capacity of 300 places. According to the State Social Service in Tirana, only $50 \%$ of the applications have been accommodated (Gedeshi \& Gjokuta, 2008).

\section{Consumption Needs and Living Standards}

Research has indicated that needs and tastes of people change over their life cycle. Usually elderly people spend the majority of their modest monthly income on health, housing and social services (Lee \& Mason, 2007). In an aging society, this means that an increasing percentage of elderly people with low or no monthly income will decrease the purchasing power of the family and society, as a whole. Elderly people have lower levels of consumption. Their demand has shifted towards basic goods. Therefore, the change of the structure of the demand will change the taste and preferences of agedependents (UN, 2007).

On the other hand, old age is associated with declining living standards increasing the vulnerability of elderly people to poverty. For those who are unprotected or lack family support this means that they have to continue working regardless of their age and work opportunities. The risk is higher for single, childless and widowed women who live alone and usually rely on survivor's benefits. Having a higher longevity than men, they tend to be vulnerable for longer periods (UN, 2007).

Data indicate that in Albania there were 37,000 elderly people living below the poverty line in 2011 (Bordogna, 2013), while in rural areas, only 9\% of the pensioners derive from the pension scheme a monthly allowance that exceeds the subsistence level (Poteraj, 2012). 


\section{Conclusions}

Population aging in Albania is the result of the socio-economic and political transition from a socialist to a capitalist society. The pace of population aging questions whether traditional family norms will continue to be supportive and giving for their old members. Limited data and research available about the diversity of family forms and living arrangements during the years of transition show that they have impacted both intergenerational coresidence and contribution to family life. Different from Western European countries, which became affluent before they turned into aging societies (Hoff, 2008), Albania is facing the aging of its population before it had the chance to be rich. This means that its poor welfare state is unable to deal with the rising burden of care for its elderly people.

But an unfavourable macro-level welfare situation might increase the pressure on micro-level family resources to provide care for the old generation. In fact, families are not fully prepared for welcoming the progressive aging of their elderly members. As part of a youth-oriented society they have built their life in such a way that it is difficult to be navigated by elderly people (Carstensen \& Fried, 2012). Therefore, transfer of income and support to old generations depends on the level of economic development of the society and the influence of cultural norms.

Moreover, taking into consideration the diversity of ethnic groups in Albania, it is important to conduct more research into how population aging is perceived among these groups in order to analyze factors that lead to similarities or differences and tailor relevant policies and programmes to address them. It should be emphasized that images of old age with negative connotations and stigma minimize the possibilities of elderly people to be socially included. Therefore, more research is needed to find out some of the ways to promote healthy old age instead of looking at it as a burden. 


\section{References}

1. Albertini, M., Kohli, M., \& Vogel, C. (2007). Intergenerational transfers of time and money in European families: Common patterns - different regimes? Journal of European Social Policy, 17, 319-334.

2. Aleksandrova, S., \& Velkova, A. (2003). Population aging in Balkan countries. Folia Medica, 4, 5-10.

3. Bacovic, M. (2007). Demographic Changes in transition countries: Opportunity or Obstacle for Economic Growth? Case of Montenegro. European Research Studies, 11 (Special Issue 3-4), 31-44.

4. Baltes, P. B., \& Smith, J. (2003). New frontiers in the future of aging: from successful aging of the young old to the dilemmas of the fourth age. Gerontology, 49, 123-135.

5. Barker, J., \& Bury, M. (1978). Mobility and the elderly: A community challenge. In. V. Carver., \& P. Liddiard (Ed.). An aging population. A Reader and Sourcebook. Open University, 179-192.

6. Barnhill, L. R., \& Longo,D. R. N. (1978). Fixation and Regression in the Family Life Cycle. Fam. Proc, 17, 469-477.

7. Bordogna, T. M. (2013). Migrations and care services: strategic options for a social development policy in Albania. Working Papers 78/2013. CESPI, Fondazione CARIPLO, Albania Domani.

8. Bornat, J., Brian, D., Jones, D., \& Peace, Sh. (1999). Stepfamilies and older people: evaluating the implications of family change for an aging population. Aging and Society, 19(2), 239-261.

9. Carella, M. \& Parant, A (2014) Demographic trends and challenges in the Mediterranean. South-East European Journal of Political Science, 2(4),

10. Carstensen, L. L., \& Fried, P. L. (2012). The meaning of old age. In. Global population aging: Peril or Promise? World Economic Forum, 15-17.

11. Carter, B., \& McGoldrick, M. (Ed.). (1999). The expanded family life cycle: Individual, family and social perspectives. $3^{\text {rd }}$ Edition. Boston: Allyn \& Bacon.

12. Christen, K., Doblammer, G., Rau, R., \& Vaupel, W. J. (2009). Aging populations: the challenges ahead. Lancet, 374, 1196-1208.

13. Coleman, M., Ganong, L. H., \& Rothrauff, T. C. (2006). Racial and ethnic similarities and differences in beliefs about intergenerational 
assistance to adults after divorce and remarriage. Family Relations, 55, 576-587.

14. De Soto, H., Gordon, P., Gedeshi, I., \& Sinoimeri, Z. (2002). Poverty in Albania: A qualitative assessment. World Bank Technical Paper 520. Washington, DC.

15. Długosz, Z. (2011). Population aging in Europe. The $2^{\text {nd }}$ International Geography Sympozium GEOMED 2010. Procedia Social and Behavioral Sciences, 19, 47-55.

16. Duvall, E. M., \& Hill, R. L. (1948). Report of the committee on the dynamics of family interaction. Washington, DC: National Conference on Family Life.

17. Erickson, M. J. (2007). Re-visioning the family life cycle theory and paradigm in marriage and family therapy. The American Journal of Family Therapy, 26(4), 341-355.

18. Ermisch, J. F., \& Francescon, M. (1996). The increasing complexity of Family Relationships: Lifetime Experiences of Single Motherhood and Stepfamilies in Great Britain. University of Essex: ESRC Research Center on Micro-social change.

19. Falkingham, J., \& Gjonça, A. (2001). Fertility transition in Albania, 1950-1990. Population Studies, 55(3), 309-319.

20. Ferreira, M. (2009). Protecting older persons against violence, abuse and discrimination. UNFPA, UN Programme on aging, Norwestern University, DOHA International Institute, 7-9.

21. Frankenberg, E., Lillard. L., \& Willis, R. J. (2002). Patterns of intergenerational transfers in Southeast Asia. Journal of Marriage and Family, 64, 627-641.

22. Gedeshi, I., \& Gjokuta, E. (2008). Migrant cities research. British Council Albania.

23. Gedeshi, I., \& Jorgoni, E. (2012). Social impact of emigration and ruralurban migration in Central and eastern Europe. Final Country Report. GVG \& EU.

24. Giddens, A. (1991). Modernity and Self Identity. Polity Press, Cambridge.

25. Gierveld, J.J. (2009). Living arrangements and differences in family support: A comparative perspective. UNFPA, UN Programme on aging, Norwestern University, DOHA International Institute, 7-9. 
26. Goldenberg, I., \& Goldenberg, H. (2004). Family Development: Continuity and Change. In. Family therapy: An Overview. $6^{\text {th }}$ Edition. Thompson Books/Cole. Pacific Grove, CA, 270-298.

27. Gondo, Y. (2012). Longevity and successful ageing: implications from the oldest old and centenarians. Asian Journal of Gerontology and Geriatrics 7, 39-43.

28. Gorman, M. (1999). Development and the Rights of Older People. In. Randel, J et al., (Ed.). The Aging and Development Report: poverty, independence, and the world's older people. London, Earthscan Publications Ltd, 3-12.

29. Gjonça, A., Aassve, A., \& Mencarini, L. (2008). Albania: Trends and patterns, proximate determinants and policies of fertility change. Demographic Research, 19(11), 261-292.

30. Gjonça, A. \& Gjonça, E. (2011.) Demographic changes and aging process in Central and eastern Europe: How sustainable and are the demographic trends for the Future? P. 227-247 In A. Hoffs (Ed.) Population Aging in Central and Eastern Europe. New perspectives on ageing and later life. Ashgate Publishing Limited , Englad.

31. Harman, D. (1956). Aging: A theory based on free radical and radiation chemistry. Journal of Gerontology, 11, 298-300.

32. Harper, S., \& Levin, S. (2003).Changing families as societies age: care, independence and ethnicity. Working paper 503. Oxford Institute of Aging, University of Oxford.

33. Havighurst, R. (1953). Human development and education. New York: Longmans, Green and Company.

34. Herlitz, C., \& Dahlberg, L. (1999). Causes of strain affecting relatives of Swedish oldest elderly. Scandinavian Journal of Caring Sciences, 13, 109-115.

35. Hill, R. (1986). Life cycle stages for types of single-parent families: of family development theory. Family Relations, 35(1), 19-29.

36. Hill, R., \& Rogers, R. (1964). The developmental approach. In. H. Christensen. (Ed.). Handbook of marriage and the family. Chicago: Rand-Mcvally, 171-192. 
37. Hoff, A. (2008). Population aging in Central and Eastern Europe as an outcome of the socio-economic transition to capitalism. Socialinis Darbas, 7(2), 14-25.

38. INSTAT. (2002). The population of Albania in 2001: Main results of the Population and Housing Census. Tirana, Instituti i Statistikes.

39. INSTAT. (2010). Albanian Demographic and Health Survey 2008-2009. Tirana. Albania.

40. INSTAT. (2014). Shqiperi: Popullsia dhe dinamikat e sajhorizonte të reja demografike.

41. Jakovljević, M., \& Laaser, U. (2015). Population aging from 1950 to 2010 in seventeen transitional countries in the wider region of South Eastern Europe. South Eastern Europe Journal of Public Health.

42. Kirk, D. (1996). Demographic Transition Theory, Population Studies, 50, 361-387.

43. Kliman, J., \& Madsen, W. (1999). Social class and the family life cycle. In B. Carter \& M. McGoldrick (Eds.), The expanded family life cycle: Individual, family, and social perspectives, Needham Heights, MA: Allyn \& Bacon, 88-105.

44. Kohli, M. (2004). Intergenerational transfers and inheritance: A comparative view. Annual Review of Gerontology and Geriatrics, 24, 266-289.

45. Lee, R., \& Mason, A. (2007). Population aging, wealth, and economic growth: demographic dividends and public policy. Background paper prepared for World Economic and Social Survey 2007.

46. Lin, I. (2008). Consequences of parental divorce for adult children's support of their frail parents. Journal of Marriage and Family, 70, 113-128.

47. Lloyd-Sherlock, P. (2000). Population aging in developed and developing regions: implications for health policy. Social Science and Medicine, 51, 887-895. 
48. Lukic, T., Stojsavljevic, R., Durdev, B., Nad, I., \& Dercan, B. (2012). Depopulation in the Western Balkan Countries. European Journal of Geography, 3(2), 6-23.

49. Muenz, R. (2007). Aging and Demographic Change in European Societies: Main Trends and Alternative Policy Options. Discussion Paper 0703, The World Bank.

50. National Institute on Aging (NIA) \& National Institute of Health (NIH). (2012). Global Health and Aging.

51. Palloni, A. (2009). Introduction. In. Family support networks and population aging, UNFPA, UN Programme on aging, Norwestern University, DOHA International Institute, 7-9.

52. Perlman, D., \& Peplau, L. A. (1981). Toward a social psychology of loneliness. In. R. Gilmour., \& S. Duck. (Ed.). Personal relationships 3: personal relationships in disorder. London Academic Press, 31-43.

53. Pezzin, L. E., \& Schone, B. S. (1999). Parental marital disruption and intergenerational transfers: An analysis of lone elderly parents and their children. Demography, 36, 287-297.

54. Poteraj, J. (2012). Pension system in Albania. IJRRAS, 11(1), 8288.

55. Rice, J. K. (1994). Reconsidering research on divorce, family life cycle, and the meaning of family. Psychology of Women Quarterly, 18, 559-584.

56. Riley, M. N., Kahn, R. L., Foner, A., \& Karin, A. (1994). Age and structural lag: Society's failure to provide meaningful opportunities in work, family and leisure. Oxford: John Wilkey \& Sons.

57. Rueda, A.C.M., \& Ferreira, R.M. (2012). The Social Construction of "Feeling of Burden": Narrative on dependency and care in old age. Revista Perspectivas Sociales, 14(2), 69-100.

58. Sanderson, W., \& Scherbov, S. (2008). Rethinking Age and Aging. Population Bulletin, 63(4), 1-18.

59. Ševo, G., Despotovic, N., Erceg, P., Jankelic, S., Milosevic, P. D., \& Davidovic, M. (2009). Aging in Serbia. Adv. Gerontol, 22(4), 553-557. 
60. Silverstein, M., \& Giarrusso, R. (2010). Aging and Family Life: A Decade Review. Journal of Marriage and Family, 72, 10391058.

61. Standing, G. (1996). Social problems in Eastern and Central Europe. In. Esping-Andersen, G. (Eds.). Welfare states in transition. National adaptations in global economies. London: Sage, 225-255.

62. Stein, C. H. (1992). Ties that bind: Three studies of obligation in adult relationship within family. Journal of Social and Personal Relationships, 9, 525-547.

63. Stein, C. H. (1993). Felt obligation in adult family relationships. In. Duck, S. (Ed.). Social context and relationships. Newbury Park, CA, SAGE, 78-99.

64. Stein, C. H., et al. (1998). Because they are my parents. An intergenerational study of felt obligation and parental caregiving. Journal of Marriage and the Family, 60, 611-622.

65. Strehler, B. L. (1977). Time, Cells and Aging, $2^{\text {nd }}$ Edition, Academic Press, New York.

66. Tinker, A. (2002). The social implications of an aging population. Mechanisms of Aging and Development, 123, 729-735.

67. The World Bank. (2010). World Development Indicators.

68. Tunstall, J. (1966). Old and Alone. London: Routlege \& Kegan Paul.

69. UN. (2007). World Economic and Social Survey 2007: Development in an Aging World, Department of Economic and Social Affairs.

70. van Groenan, B. M., Glaser, K., Tomassini, C., \& Jacobs, T. (2006). Socio-economic status differences in older people's use of informal and formal help: A comparison of four European countries. Aging and Society, 26, 745-766.

71. Vină, J., Borràs, C., \& Miquel, J. (2007). Theories of aging. Life, 59(4), 249-254.

72. Vojković, G., Magdaenić, I., \& Živanović, Z. (2014). Population aging and its impact on labor force in the South East Europe 
Countries. Zbornik Matice srpske za drustvone nauke, 148, 702715.

73. Walker, A., \& Maltby, T. (1997). Aging in Europe. Open University Press, Buckingham.

74. Warnes, A. (1998). Background report on Demographic Ageing and Late-Age Mortality Trends in Europe. Report for SCOPE, BioMed II. Project. University of Sheffield, U.K.

75. World Bank. (2011). Migration and Remittances Factbook.

76. Zahidi, S. (2012). Women and aging. In. Global Population Aging: Peril or Promise, 21-24.

77. Zilbach, J. J. (1989). The family life cycle: A framework for understanding children in family therapy. In. Combrinck-Graham (Ed.). Children in family contexts: Perspectives on treatment. New York: Guilford Press. 